\title{
Står på språkkrava
}

\section{Seksjonsoverlege Ottar Rekkedal har dysleksi og er ein hardbarka nynorskforkjempar. No er han tildelt prisen Årets nynorskbrukar 2009.}

Prisen vert delt ut av Nynorsk kultursentrum, og gynekologen frå Lillehammer får prisen for viljen til å gjere nynorsk til eit alminneleg språk også i norsk helsevesen og for å vidareutvikle nynorsk som medisinsk fagspråk i bruken av moderne informasjonsteknologi. Rekkedal seier han har følt seg litt åleine i språkkampen mot norsk helsevesen, i det siste mot Helse Sør-Øst.

- Det er ein kontinuerleg kamp. Ingenting er lagt til rette for å vere ein aktiv nynorskbrukar, og eg har til tider følt meg mobba og trakassert når eg har teke opp saka. Den språklege rasismen innafor offentleg forvaltning er mykje sterkare enn nokon trur, seier han.

Han dikterer konsekvent på nynorsk, men får notata tilbake på bokmål. Ofte har dei da eit lite godt språk, for direkte omsetting vil alltid gje dårleg resultat, fortel Rekkedal.

\section{Skreiv brev - fekk medhald}

Dette problemet forklarte han hausten 2008 i eit brev til administrerande direktør i Helse Sør-Øst, Bente Mikkelsen, med kopi til Kultur- og kyrkjedepartementet. Like etter fekk han svar frå Sjukehuset Innlandet med lovnad om å bli sitert ordrett heretter. I februar fekk han medhald frå departementet. Dei viser til mållova $\S 1$, der det er fastsett at bokmål og nynorsk er likeverdige målformer og skal vere jamstilte

skriftspråk i alle organ for stat, fylkeskommune og kommune. No får han notata sine attende på nynorsk.

- Sekretærane yter sitt beste, men når dei etter mange år plutseleg skal skrive nynorsk utan den hjelp og støtte dei burde ha fått frå arbeidsgjevarsida, så føler dei seg utrygge. Eg har stor respekt for skrivestaben på sjukehuset her på Lillehammer, men det dei presterer, presterer dei fordi dei er sporty og dyktige, ikkje fordi dei får hjelp frå arbeidsgjevaren.

\section{Mistydingar}

- Vert det først og fremst dårleg språk, eller kan det òg bli misforståingar?

- Begge delar. At språket vert endra, er det største problemet. Omformuleringa til bokmål gjer òg at nyansar vert borte og mistydingar kan oppstå. Sjølv om eg gjer meg flid med å vere nøyaktig, vert bokmålsutgåva ikkje mitt notat. Da vil ikkje eg setje signaturen min på det, seier Rekkedal.

Han meiner det ikkje vert lagt til rette for å vere nynorskbrukar, verken på Vestlandet eller på Austlandet. Ved innkjøp av datautstyr- og programvare vert det ikkje teke omsyn til nynorskbrukarane.

- I Helse Sør-Øst har vi 265 standarddokument som vi skal bruke når vi skal melde ulike sjukdommar internt $i$ organisasjonen eller til offentlege kontrollorgan. Sjølvsagt er alle berre på bokmål. Det finst

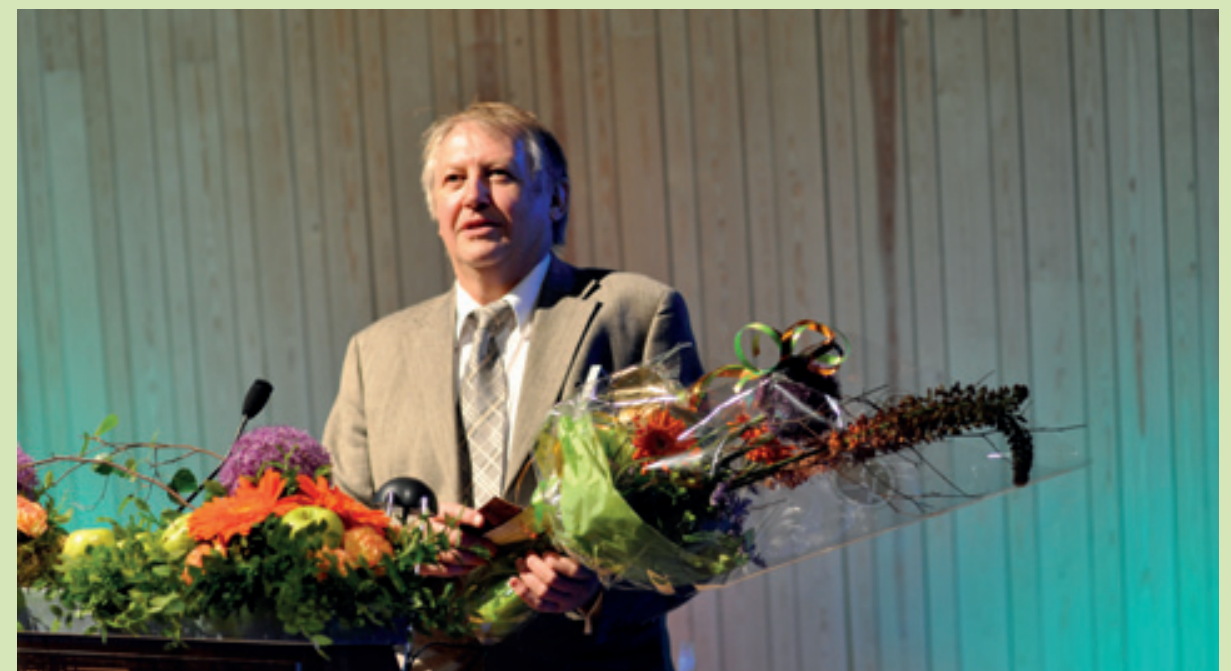

eit retteprogram for nynorskbrukarar, men det er gøymd langt vekk, og det er primitivt. Helse Sør-Øst skal innføre det nye systemet for å kjenne att tale utan omsyn til den nynorske målforma. Det ligg ikkje i kravspesifikasjonen til systemet at det skal takle begge målformene, noko dei pliktar til ifølgje lov om helseføretaka, forvaltningslova og mållova. Det er hovudlaust, seier Rekkedal. Han etterlyser ein strategi frå Helse Sør-Øst.

- Strategien deira i dag er å gje faen i nynorsk, seier Rekkedal.

\section{Tek til etterretning}

HR-direktør i Helse Sør-Øst, Vidar Lødrup, seier til Tidsskriftet at helseføretaket skal drive verksemda si i tråd med lova, inkludert mållova.

- Vi har teke til etterretning vurderingane frå Kultur- og kyrkjedepartementet om korleis vi skal følgje mållova sine føringar for dei aktuelle rutinane. Vi har også formidla presiseringane vidare til Sjukehuset Innlandet, seier Lødrup.

\section{Taleattkjenning på nynorsk}

Kultur- og kyrkjedepartementet viste i brevet sitt til at også andre sjukehus enn Sjukehuset Innlandet vil bruke systemet for å kjenne att tale. «I og med at nynorsk og bokmål er offisielt likeverdige og likestilte målformer, kan man på landsbasis vanskelig tenke seg at det offentlige kan ta i bruk talegjenkjenningssystemer som ikke kan håndtere begge målformer,» heiter det i brevet datert 2. januar 2009.

Vidar Lødrup seier at det no vert sett i gang eit forprosjekt som skal sjå på dette.

- Vi er kjend med at dei regionale helseføretaka si styringsgruppe for nasjonal IKT om kort tid vil vurdere å setje i gang eit forprosjekt. Da vil vi få avklart korleis vi i fellesskap kan lage eit system for begge målformene, seier Lødrup.

\section{Eline Feiring}

eline.feiring@legeforeningen.no

Tidsskriftet 